\title{
Perilaku Bullying pada Anak di Taman Kanak-kanak
}

\author{
Ning Tyas Maghfiroh ${ }^{1}{ }^{\bowtie}$, Sugito $^{1}$ \\ Pendidikan Anak Usia Dini Universitas Negeri Yogyakarta, Indonesia(1) \\ DOI: $\underline{10.31004 / \text { obsesi.v6i3.1845 }}$
}

\begin{abstract}
Abstrak
Perilaku bullying merupakan salah satu permasalahan sosial yang sering terjadi. Tujuan dari dilakukannya penelitian ini yaitu untuk dapat memberikan sebuah gambaran secara faktual tentang prilaku-prilaku bullying yang dilakukan pada anak prasekolah. Menggunakan metode kuantitatif dengan pendekatan studi kasus. Subjek penelitian ini adalah seluruh anak-anak di Raudhatul Athfal Al-Islam usia 5-6 tahun. Kemudian pengambilan sampel menggunakan teknik purposive random sampling, diperoleh partisipan sebanyak 10 anak, 5 partisipan mewakili korban bully dan 5 lainnya mewakili pelaku bullying. Kemudian teknik pengumpulan data yaitu melalui observasi dan dikperkuat dengan wawancara. Berdasarkan data yang diperoleh dilakukan lah uji keabsahan dengan menggunakan triangulasi waktu untuk memperoleh data yang akurat dalam penelitian ini. Selanjutnya dianalisis menggunakan teknik analisis tematik. Hasil penelitian menunjukkan bahwa ada tiga jenis perilaku bullying yaitu perilaku bullying fisik, verbal, dan psikologis. Dari penelitian yang telah diteliti bahwa pelaku merupakan anak yang sama dan korban juga anak yang sama dan lemah.
\end{abstract}

Kata Kunci : anak usia dini; perilaku bullying; taman kanak-kanak.

\begin{abstract}
Bullying behavior is one of the most common social problems. The purpose of this research is to be able to provide a factual picture of bullying behaviors that are carried out in preschool children. Using quantitative methods with a case study approach. The subjects of this study were all children in Raudhatul Athfal Al-Islam aged 5-6 years. Then the sample was taken using a purposive random sampling technique, obtained as many as 10 participants, 5 participants representing victims of bullying and 5 others representing bullies. Then the data collection technique is through observation and strengthened by interviews. Based on the data obtained, the validity test was carried out using time triangulation to obtain accurate data in this study. Then analyzed using thematic analysis techniques. The results showed that there were three types of bullying behavior, namely physical, verbal, and psychological bullying. From the research that has been researched that the perpetrator is the same child and the victim is also the same and weak child.
\end{abstract}

Keywods : early childhood; bullying behavior; kindergarten.

Copyright (c) 2021 Ning Tyas Maghfiroh, Sugito

$\triangle$ Corresponding author :

Email Address : ningtyasmaghfiroh22@gmail.com (Yogyakarta, Indonesia)

Received 9 August 2021, Accepted tanggal 21 December 2021, Published 30 December 2021 


\section{PENDAHULUAN}

Pada era globalisasi seperti yang terjadi pada saat ini, banyak sekali muncul masalah dalam pendidikan anak usia dini salah satunya perilaku bullying. ICRW (International Center For Research on Women) yang melakukan penelitian di tahun 2015, menemukan ada 84\% anak Indonesia yang mengalami kasus kekerasan yang terjadi di sekolah. Persentase tersebut merupakan angka yang lebih tinggi daripada kasus kekerasan di sekolah yang terjadi di kawasan Asia (Aini, 2018). Sementara pada tahun 2019 PISA (Programme for Internasional Students Assesment) menemukan bahwa di negara Indonesia masih banyak anak yang mengalami perilaku bullying yaitu sebesar $41 \%$. Kondisi ini lebih tinggi bila dibandingkan dengan negara anggota OECD (Organisation For Ecomomic Co-operation and Development) yaitu sebesar $22,7 \%$. Indonesia menempati urutan kelima dari 78 negara yang mengalami kasus bullying yang terjadi pada siswa (Amalia et al., 2021). Perilaku bullying dapat mulai terjadi pada masa kanak-kanak pada usia 3 tahun. Dimana, anak mulai berpartisipasi langsung dalam perilaku bullying (Ambarini et al., 2019).

Perilaku bullying sendiri merupakan perilaku yang tidak diharapkan terutama pada lingkungan sekolah karena bully termasuk salah satu perilaku agresif. Menurut Janitra \& Prasanti (2017) bullying merupakan suatu bentuk perilaku bersifat negatif yang dilakukan secara berulang kali, dalam keadaan sadar dan sengaja dengan maksud dan tujuan untuk dapat menyakiti orang lain baik itu dalam bentuk menyakiti secara fisik, maupun secara emosional yang dilakukan secara perorangan ataupun berkelompok. Sejalan dengan pendapat tersebut (Mahriza et al., 2021) mengatakan bahwa suatu perilaku bullying merupakan tindak kekerasan yang dapat terjadi seperti pemaksaan baik itu dilakukan dalam bentuk fisik maupun psikologis kepada anak ataupun orang yang lebih lemah. Perilaku agresif ini biasanya dilakukan dengan sengaja, terus-menerus dan berulang-ulang secara fisik, verbal bahakan terkadang juga ada yang melakukan bullying secara psikologis. (Azzahra et al., 2021) mengelompokkan perilaku menjadi empat jenis yaitu antara lain (1) dalam bentuk fisik, (2) bullying dalam bentuk lisan ataupun bullying dalam bentuk verbal (3) bullying psikis dan yang terakhir (4) cyberbullying, cyberbullying ini merupaklan perilaku bully dengan menggunakan media elektronik seperti internet maupun telepon atau lainnya, contohnya antra lain seperti memposting sesuatu dalam bentuk teks, video, gambar atau foto yang digunakan pelaku bully untuk menakut-nakuti, mengancam ataupun intimadasi si korban bully tersebut.

Tindakan perilaku bullying biasanya dimaksudkan dengan tujuan untuk memperlihatkan kekuasaan orang tersebut dengan cara menyakiti seseorang ataupun sekelompok orang, baik dilakukan secara verbal ataupun dilakukan secara non verbal yang akan menyebabkan korban perilaku bullying tersebut menjadi depresi, lemah, terkadang juga korban merasa teraniaya sehingga membuat trauma pada diri korban tersebut (Siron et al., 2021). Perilaku bullying pada anak terjadi sejak anak usia taman kanak-kanak atau ketika anak berusia 5-6 tahun dan puncak permasalahannya ketika anak pada usia sekolah menengah (Olweus, 1997). Anak yang melakukan bullying biasanya melakukan tindakan seperti; mencubit, mengejek, memukul, mengancam, merusak barang orang lain, mendorong, menjulurkan lidah, mencakar, pemalakan serta segala bentuk perilaku penidasan, dan lain sebagainya. Sehingga hal tersebut dapat mengganggu ataupun menyakiti orang lain yang dilakukan secara sadar, sengaja dan terjadi berulang-ulang. Berbeda dengan perilaku kekerasan lainya perilaku bullying dapat terjadi berulang ulang kali jika pelaku mendapatkan kesempatan untuk melakukan aksinya terhadap korban. Sejalan dengan pendapat tersebut (Artanti et al., 2021) mengemukakan bahwa perilaku bullying merupakan suatu hasrat untuk dapat menyakiti orang lain, selanjutnya hasrat ini jugalah yang menjadi aksi dari pelaku bully untuk membuat korbannya menjadi menderita.

Selanjutnya, terdapat beberapa faktor yang menyebabkan timbulnya perilaku bullying pada anak diantaranya yaitu; faktor dari individu itu sendiri, faktor yang terjadi di lingkungan keluarga, faktor yang berasal dari teman sebaya, faktor lingkungan dalam 
masyarakat, faktor yang berasal dari sekolah dan bahkan bisa juga faktor yang timbul dari media terhadap pelakunya. Hal ini sejalan dengan pendapat Kasanah (2013) yang mengatakan bahwa terdapat beberapa faktor penyebab terjadinya perilaku bullying yang terjadi di lingkungan sekolah salah satunya adalah faktor internal meliputi harga diri anak yang ingin dianggap super oleh orang lain dan pemahaman moral anak yang kurang, sedangkan foktor eksternalnya meliputi sikap orang tua dalam berperilaku atau memberi contoh pada anaknya, keluarga yang terlalu memanjakan anak, orang tua yang kurang tegas dalam mendidik anak dan tayangan televisi yang kurang cocok untuk ditonton oleh anak-anak. Selain dari beberapa faktor lainnya adalah iklim sekolah yang kurang kondusif juga menjadi salah satu penyebab munculnya perilaku bullying (Surilena, 2016).

Kemudian, dari adanya perilaku bullying yang terjadi memunculkan banyak dampak antara lain korban bullying biasanya memiliki perasaan takut, terancam dan tidak berdaya. Kondisi seperti inilah yang akan menyebabkan kepercayaan diri anak menjadi turun, anak menjadi trauma, merasa bahwa dirinya selalu sendiri, malu, serba salah, takut sekolah (school phobia), anak tidak mampu untuk menyerang balik, dan merasakan bahwa ia tidak ada orang yang menolong. Sebaliknya dampak yang akan tibul dari seorang pelaku bullying antara lain menjadi tidak memiliki rasa empati, akan cenderung bersifat egois dan akan dijauhi oleh teman (Kasanah, 2013).

Namun, sayangnya masyarakat, guru, orang tua, dan pihak lainya masih seringkali abai dengan perilaku bullying yang terjadi disekitarnya, serta menganggap bahwa perilaku bullying yang terjadi pada anak adalah hal yang biasa terjadi pada kehidupan sehari-hari. Padahal ketika anak berusia prasekolah perilaku dan sikap anak dapat dikontrol sehingga perilaku bullying dapat diminimalisir. Sejalan dengan pendapat tersebut, (Putri et al., 2020) juga mengungkapkan hal serupa bahwa bentuk perilaku bullying yang dilakukan oleh anak usia dini seringkali diabaikan oleh orang tua ataupun orang dewasa yang ada dilingkungan sekitar anak, tak jarang guru pun juga mengabaikan bentuk perilaku bullying yang dilakukan oleh anak usia dini ini dengan beranggapan dimana anak dengan usia sedini itu belum dapat memahami mana perilaku yang baik ataupun perilaku buruk, sehingga wajar dilakukan oleh anak tersebut. Hal ini disebabkan karena minimnya pengetahuan yang dimiliki oleh guruguru di sekolah anak usia dini tentang perilaku bullying. Padahal, sebenarnya guru-guru telah banyak mendengar maupun membaca kasus-kasus bullying yang terjadi pada anak usia dini di berbagai media, hanya saja guru juga tidak menyadari bahwa mungkin saja kasus bullying tersebut terjadi pada anak-anak yang berada di lingkungan sekolah tempat ia mengajar.

Selanjutnya bila kasus bullying pada anak ini terus saja terjadi dan terus saja diabaikan oleh orang dewasa disekitar anak, bukan tidak mungkin bahwa perilaku bullying ini akan terus dilakukan anak hingga anak dewasa. Sependapat dengan (Ambarini et al., 2018) yang menyatakan bahwa bila perilaku pada anak usia dini terus terjadi dan tidak segera dihentikan maka pelaku akan terus menerus melakukan perilaku bullying sampai anak tersebut remaja, sebaliknya korban bullying tersebut akan tetap mengalami pembullyan atau akan tetap mengalami penderitaan secara berkelanjutan. Sedangkan perilaku bullying ini jika dibiarkan terus menerus maka akan terjadi pola-pola perilaku bullying dan akan menimbulkan berbagai efek yang dapat diderita oleh si korban bullying sehingga sering sekali terjadi hubungan yang kurang baik hingga anak tumbuh dewasa.

Berdasarkan observasi yang telah peneliti lakukan di RA Al-Islam Muaro Jambi peneliti menemukan beberapa permasalahan di lapangan, seperti salah satunya anak belum dapat melakukan pola pertemanan yang baik dengan teman sebayanya, beberapa anak masih suka pilih-pilih dalam berteman dan mengucilkan teman lainnya, bahkan ada juga anak yang melakukan kekerasan fisik pada temannya seperti perilaku menendang, memukul, mencubit serta mendorong temannya. Hal ini miris sekali, dimana seharusnya perilaku kekerasan atau bullying seharusnya tidak terjadi pada anak. Namun pada kenyataanya anak telah menjadi korban dan pelaku dari tindak bullying. Untuk itu penelitian ini dirasa perlu dilakukan guna melihat lebih dalam mengenai gambaran perilaku bullying yang terjadi pada anak usia dini. 


\section{METODOLOGI}

Metode yang digunakan dalam penelitian ini adalah metode kualitatif dengan menggunakan pendekatan studi kasus. Metode kualitatif ini dipilih karena peneliti akan masuk langsung kepada objek yang dituju dengan maksud untuk dapat mengungkapkan permasalahan yang sedang diteliti dalam lingkungan penelitian secara luas, menyeluruh dan mendalam. Melalui pendekatan studi kasus dalam penelitian ini juga dimaksudkan untuk lebih mendalami lagi suatu kasus tertentu secara lebih mendalam dengan melibatkan beberapa sumber informasi. (Raco, 2018) menyatakan bahwa pendekatan melalui studi kasus dapat membantu peneliti untuk dapat mengadakan studi mendalam mengenai perorangan, kelompok, organisasi, daerah, budaya, agama atau sebuah negara. Tujuan dari dilakukannya penelitian ini yaitu untuk dapat memberikan sebuah gambaran secara faktual tentang prilakuprilaku bullying yang dilakukan pada anak usia dini.

Subjek dalam penelitian ini adalah seluruh anak-anak yang bersekolah di Raudhatul Athfal Al-Islam dengan rentang usia 5-6 tahun. Kemudian dilakukan pengambilan sampel menggunakan teknik purposive random sampling dengan kriteria anak pembully yaitu tidak memiliki rasa empati, egois, mengucilkan temannya, memukul, mencubit, mengejek, mendorong. Selanjutnya anak korban bullying yaitu murung, tidak percaya diri, penakut, menyendiri, bahkan takut untuk sekolah. Sehingga diperoleh partisipan sebanyak 10 anak, dimana 5 partisipan mewakili korban bully dan 5 lainnya mewakili pelaku bullying. Kemudian teknik pengumpulan data dari penelitian yang dilakukan yaitu melalui observasi dan dikperkuat dengan wawancara bersama 5 guru sebagai informan yang mana setiap guru mewakili satu anak pelaku bullying dan satu anak korban bullying. Kemudian berdasarkan data yang diperoleh dilakukan lah uji keabsahan dengan menggunakan triangulasi waktu untuk memperoleh data yang akurat dalam penelitian ini. Selanjutnya dianalisis menggunakan teknik analisis tematik. Yang mana teknik analisis tematik sendiri merupakan sebuah cara untuk menganalisa data yang telah dikumpulkan oleh peneliti dengan maksud dan tujuan untuk mengidentifikasi pola agar menemukan sebuah tema yang tersusun sesuai dengan pernyataan peneliti sehingga dapat menjadikan acuan dalam pemaparan yang sedang diteliti (Heriyanto, 2018).

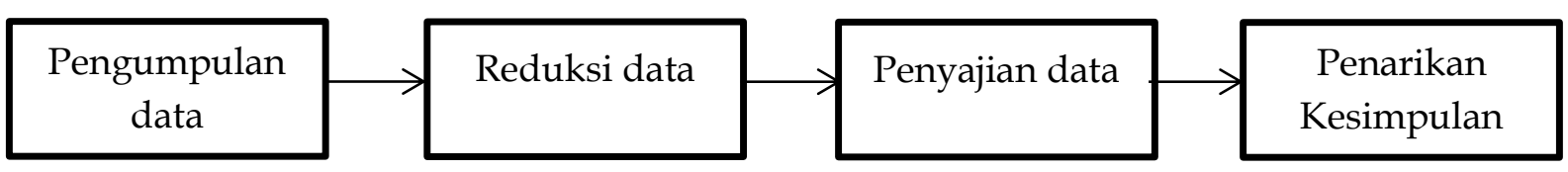

Gambar 1. Alur Penelitian

\section{HASIL DAN PEMBAHASAN}

Berdasarkan hasil penelitian yang telah peneliti lakukan, maka dapat ditemukan ketiga jenis bentuk perilaku bullying yang terjadi di sekolah RA Al-Islam Muaro Jambi yaitu bullying dalam bentuk fisik, bullying verbal dan bullying dalam bentuk psikologi yang akan dibahas sebagai berikut.

\section{Bullying dalam bentuk fisik}

Pada bullying fisik perilaku yang terjadi berupa mendorong, mencubit, menendang, merusak barang atau mainan serta memukul. Selanjutnya, dari hasil wawancara yang peneliti lakukan dengan beberapa informan tentang perilaku-perilaku yang terkait bullying secara fisik misalnya apakah ada perilaku anak yang memukul, menendang, mencubit, mendorong ataupun merusak mainan temannya? Seberapa sering perilaku tersebut dilakukan? Kira-kira apa penyebab dari perilaku tersebut? Selanjutnya informan menyatakan bahwa ada beberapa anak yang melakukan perilaku bullying. Selain itu informan juga menyatakan bahwa perilaku bullying ini sering dilakukan oleh anak yang kuat terhadap temannya yang lebih lemah. 
“...anak cewek yang sedang main nyusun-nyusun balok mainan terus si anak cowo satu ini datang mengganggu merubuhkan mainannya si teman cewek itu, tanpa sebab. Hampir setiap kali anak cewe ini main dia berulah merusak dengan sengaja mainan temannya..." (kutipan wawancara bu PA)

"... satu ini anak yang suka mendorong tiba-tiba nanti temannya terdorong, menarik temannya tanpa sebab tidak jarang temannya ini sampai menangis karena ulah dari pelaku tersebut dan ada satu orang anak suka memukuli temannya merebut mainan, mengambil pensil temannya yang sedang belajar, mendorong temannya sampe nangis..." (kutipan wawancara bu VN)

Dari hasil-hasil temuan yang didapatkan, temuan tersebut dapat menunjukkan bahwa anak-anak di RA Al-Islam Muaro Jambi teridentifikasi pada tindak perilaku bullying. Hal ini dapat terungkap berdasarkan keterangan-keterangan yang diberikan informan dan juga diperkuat dengan adanya temuan langsung peristiwa-peristiwa tersebut dilapangan. Untuk jenis bullying yang dilakukan melalui fisik yaitu ada anak yang memukul, menendang, mendorong, adapula anak yang merusak mainan temannya sedang asik bermain dan masih banyak lagi perilaku-perilaku lainnya. Hal tersebut sering kali terjadi disekolah itu dan untuk korban maupun pelaku adalah anak yang sama yaitu anak yang lemah ditindas oleh anak yang lebih kuat. Hal ini sesuai dengan pendapat Olweus, (1997) tentang teori bullyinya yang menyatakan bahwa bullying merupakan suatu perilaku negatif dengan maksud menyebabkan ketidak senangan dan menyakitkan yang dilakukan oleh seseorang ataupun beberapa orang secara langsung kepada orang yang dianggapnya lemah dan dilakukan secara berulangulang.

\section{Bullying dalam bentuk verbal}

Perilaku bullying verbal yang terjadi berupa mengejek, mengolok-olok dan memarahi korbannya, sedangkan perilaku bullying psikologi seperti mengucilkan dan membuat korban menjadi menangis. Selanjutnya pada indikator perilaku bullying secara verbal yaitu apakah sering terdengar anak mengejak, memarahi, mengolok, menteriaki ataupun mengancam temannya? Seberapa sering perilaku tersebut terjadi? Kira-kira apa penyebab perilaku tersebut dilakukan? Informan menyatakan bahwa sering kali terdengar anak-anak yang melakukan perilaku tersebut di RA-Al-Islam Muaro Jambi. Perilaku yang kerap sekali terdengar yaitu seperti menteriaki, mengejek, mengolok-olok dan mengancam temannya.

"... si anak sudah mulai bergaul dengan orang dewasa, bahasanya pun sudah mengikuti seperti bahasa orang dewasa, jadi ngaruh bahasa orang dewasa itu terbawa pada anak sampai anak sekolah. Itu terjadi karena main tapi gak seumuran tu kan. Karena semenjak covid-19 ini si anak itu ikut ngaji sore di rumah kayak ngaji madrasah itu jadi berkawan dengan anak-anak lain yang umurnya jauh lebih besar. Ibu nya juga meng-iyakan bahwa ada omongan dari anaknya yg sudah berubah jauh kayak omongan orang-orang dewasa, padahal dulunya si anak ini pendiam, tapi sekarang udah ga bisa diam lagi. Ucapan yang sering diucapkan oleh anak itu adalah kata-kata kasar dan tidak baik sehingga tidak sesuai dengan umur anak yang semestinya tidak mengeluarkan omongan-omongan kasar itu ..." (kutipan wawancara bu $Y L)$

..."si Fi ini dia sering kali mengolok-olok temannya, dia suka mengolok-olok teman yang salah menggunakan seragam, dan juga suka mengolok-olok teman yang tidak sengaja BAB dicelana karena memang pada saat itu anak yang BAB dicelana itu sedang diare. Ada lagi anak yang suka meneriaki anak lainnya yang duduk disebelah kiri maupun kanannya ketika sedang berdoa, si anak ini sengaja teriak-teriak di dekat telinga temannya jadi kadang teman yang diteriaki itu mengusap-usap telinganya dan merasa sakit karena suara yang masuk teringa terlalu kencang..." (kutipan wawancara bu MA)

Berdasarkan hasil dari data yang ditemukan terkait dengan perilaku bully secara verbal, informan menyatakan bahwa sering kali terdengar ada anak yang berkata tidak baik terhadap teman sebayanya, mengejek, mengolok-olok dan masih banyak lagi perilaku yang kurang pantas diucapkan oleh anak seusianya. Hal ini juga diperkuat dengan adanya temuan 
secara langsung yang diamati oleh peneliti mengenai perilaku bully secara verbal seperti pada saat anak mengolok-olok, mengejek dan meneriaki anak lainnya. Dari pemaparan informan hal tersebut dapat terjadi dikarenakan mendapat pengaruh dari lingkungan anak bermain di luar sekolah, bahkan setelah ditanyakan kepada salah satu orang tua murid pun ia membenarkan bahwa perilaku verbal yang kurang baik itu didapat anaknya ketika anaknya sekolah di salah satu tempat mengaji sore, hal ini dikarenakan banyak anak-anak lain yang berusia cukup besar dari anaknya yang mengeluarkan kata-kata yang tidak sopan dan hal itulah yang dicontoh dan diterapkan si anak kepada teman-teman di sekolahnya. Hal ini sejalan dengan penelitian Wahyuni \& Pransiska (2019) yang mengatakan bahwa perkataan yang menyerupai perkataan orang dewasa dapat didengar ketika saat anak memanggil temannya serta mengancam atau mengintimidasi temannya yang lemah ini termasuk kedalam perilaku secara verbal. Hal tersebut sesuai dengan pendapat Sufriani \& Sari (2017) menyatakan bahwa bullying verbal merupakan bullying yang dilakukan dengan cara mengancam, memanggil seseorang dengan nada yang tidak baik, dan menyebarkan desasdesus palsu atau jahat.

\section{Bullying dalam bentuk psikologi}

Pada perilaku bullying yang dilakukan secara psikologis indikator yang akan di perhatikan dalam perilaku ini adalah apakah ditemukan anak mengucilkan, menyendiri, terlihat murung dan menangis karena ditertawakan atau ditakuti? Seberapa sering perilaku tersebut terjadi? Dan kira-kira apa penyebab perilaku tersebut dapat terjadi? Informan menyatakan bahwa sering sekali anak melakukan perilaku-perilaku tersebut.

“... ada satu orang anak yang menghasut anak lainnya agar tidak berteman dengan salah satu murid. Perilaku ini sering terjadi sehingga anak ini bilang ke guru kalo ada teman yang satu gak mau berteman sama kami dan tidak mau berbagi mainan dengannya..." (kutipan wawancara bu MA)

“.... satu orang anak laki-laki ini dia ga suka dengan salah satu teman dikelasnya, perilaku ini hampir setiap hari selama satu minggu sekolah pertama dia tidak menyukai satu orang itu. Dia akan bilang kami dak suko kawananan sama dio tu buk. Si anak ini juga menghasut teman lainnya agar tidak main sama dia sehingga anak yang tidak disukai itu merasa dikucilkan..." (kutipan wawancara bu NZ)

“... satu orang lagi dia suka sekali menakut-nakuti anak lain ketika sedang berkegiatan di kelas, dia sering menakuti teman-temannya dengan pisau mainan dan juga sesekalin dia menakuti teman lainnya dengan pistol-pistolan jika ia melihat pistol-pistol itu...." (kutipan wawancara bu WR)

Selanjutnya jenis perilaku bullying yang terakhir adalah perilaku bullying yang dilakukan secara psikologis, sesuai dengan informan yang telah penelititanyakan, yang mengatakan bahwa banyak sekali ditemukan baik yang melakukannya pelaku maupun si korban. Tambah diperkuat pada saat peneliti menemukan peristiwa tersebut secara lansung seperti perilaku terdapat anak yang tidak ingin berteman dengan sesamanya, ada juga anak yang menakut-nakuti temannya dengan menggunakan pisau mainan dan menghasut teman lainnya untuk tidak berteman dengan salah satu anak dalam kelasnya. Hal ini sesuai dengan pendapat yang diutarakan oleh Abubakar (2018) yang mengatakan bahwa bullying psikologis dapat minimbulkan dapak yang cukup berat, seperti misallnya kecemasan yang berlebihan, merasa ketakutan dan dapat menimbulkan depresi dini pada anak. Sehingga diharapkan pihak-pihak yang terkait dapat bersama-sama untuk menyelamatkan anak dari perilaku bullying yang akan berdampak negatif dalam kehidupan sehari-hari, selain itu juga dapat mencegah dampak dalam jangka panjang bagi kehidupan anak selanjutnya. 


\section{SIMPULAN}

Hasil penelitian menunjukkan bahwa terdapat tiga jenis perilaku bullying yang terjadi di RA Al-Islam Muaro Jambi yaitu dalam bentuk perilaku bullying yang dilalkukan secara fisik (memukul, menendang, mendorong dan merusak mainan teman), perilaku bullying yang dilakukan secara verbal (mengolok-olok, mengejek dan meneriaki) dan perilaku bullying psikologis (tidak ingin berteman, menakut-nakuti dan menghasut). Sehingga diperlukannya dukungan dari lingkungan sekolah khususnya guru untuk mencegah perilaku bullying lebih awal dan memberikan edukasi kepada anak agar tidak melakukan tindakan bullying.

\section{UCAPAN TERIMAKASIH}

Ucapan terima kasih disampaikan kepada Bapak Sugito selaku dosen mata kuliah Kajian Permasalahan PAUD di Pascasarjana Universitas Negeri Yogyakarta telah membekali pengetahuan dan memberi bimbingan kepada saya ketika proses penulisan jurnal dan terimakasih peneliti ucapkan kepada berbagai pihak yang terlibat dalam penelitian ini khususnya untuk guru di RA Al-Islam Muaro Jambi.

\section{DAFTAR PUSTAKA}

Abubakar, S. R. (2018). Mencegah Lebih Efektif Dari Pada Menangani (Kasus Bullying Pada Anak Usia Dini). Smart Paud, 1(1), 1-7. https://doi.org/10.36709/jspaud.v1i1.3514

Aini, D. F. N. (2018). Self Esteem Pada Anak Usia Sekolah Dasar Untuk Pencegahan Kasus Bullying. 6(April), 36-46. https:// doi.org/10.22219/jp2sd.v6i1.5901

Amalia, R., Hendriana, B., \& Vinayastri, A. (2021). Pengembangan Media Komik Elektronik untuk Mengurangi Bullying pada Siswa Anak Usia Dini. Jurnal Ilmu Pendidikan, 3(5), 2392-2401. https:// doi.org/10.31004/edukatif.v3i5.869

Ambarini, R., Indrariani, E. A., \& Zahraini, A. D. (2018). Antisipasi Pencegahan Bullying Sedini Mungkin: Program Anti Bullying Terintegrasi untuk Anak Usia Dini. 2(2). https://doi.org/10.34001/jdc.v2i2.587

Ambarini, R., Wardoyo, S. L., Sumardiyani, L., \& Zahraini, D. A. (2019). Model Program Intervensi Anti Bullying Berbasis Sekolah. LITE: Jurnal Bahasa, Sastra, Dan Budaya, 15(2), 136-160. https:/ / doi.org/10.33633/lite.v15i2.2844

Artanti, A., Novianti, R., \& Zulkifli, N. (2021). Analisis Bullying pada Anak Panti Asuhan Usia 0-6 Tahun di Panti Asuhan Ar-Rahim Pekanbaru. 5, 2848-2857.

Azzahra, S. S., Pandin, M. A., \& Pandin, M. G. R. (2021). The factors of bullying and character education on teenagers. April, 1-9. https:// doi.org/10.20944/preprints202104.0102.v1

Heriyanto. (2018). Thematic Analysis sebagai Metode Menganalisa Data untuk Penelitian Kualitatif. 2(3), 317-324. https:// doi.org/10.14710/anuva.2.3.317-324

Janitra, P. A., \& Prasanti, D. (2017). Komunikasi Keluarga Dalam Pencegahan Perilaku Bullying Bagi Anak. Jurnal Ilmu Sosial Mamangan, 6(1), 23-33. https://doi.org/10.22202/mamangan.v6i1.1878

Kasanah, I. (2013). program sahabat sebagi salah satu program alternatif penanganan bullying pada anak usia dini (pp. 364-371). https:// doi.org/10.21831/jpa.v2i2.3049

Mahriza, R., Rahmah, M., \& Santi, N. E. (2021). Stop Bullying: Analisis Kesadaran dan Tindakan Preventif Guru pada Anak Pra Sekolah. 5(1), 891-899. https://doi.org/10.31004/obsesi.v5i1.739

Olweus, D. A. (1997). Bully / victim problems in school : Facts and intervention. Europan Journal Of Psychology Of Education, XII(December 1997), 495-510. https://doi.org/10.1007/BF03172807

Putri, L. A. D., Yetti, E., \& Hartati, S. (2020). Pengaruh Keterlibatan Orangtua dan Regulasi Diri terhadap Perilaku Bullying Anak Usia Dini. Pendidikan Anak Usia Dini, 4(1), 715732. https:// doi.org/10.31004/obsesi.v4i2.438 
Raco, J. (2018). Metode penelitian kualitatif: jenis, karakteristik dan keunggulannya. https:// doi.org/10.31219/osf.io/mfzuj

Siron, Y., Mardhiah, M., Nurrahma, I. F., \& Salsabila, A. (2021). Peran Guru Dalam Menghadapi Bully Terhadap Anak Gagap Dari Teman Sebaya. Psycho Idea, 19(1), 65. https:// doi.org/10.30595/psychoidea.v19i1.7741

Sufriani, \& Sari, E. P. (2017). Faktor Yang Mempengaruhi Bullying Pada Anak Usia Sekolah Di Sekolah Dasar Kecamatan Syiah Kuala Banda Aceh. Idea Nursing Journal, 8(3).

Surilena. (2016). Perilaku Bullying (Perundungan) pada Anak dan Remaja. Cdk-236, 43(1), 3538.

Wahyuni, V., \& Pransiska, R. (2019). Perilaku bullying pada Anak Usia 5-6 Tahun Studi Kasus di Taman Kanak-Kanak. Journal of Family, Adult, and Early Childhood Education, $1(2), 160-166$. 